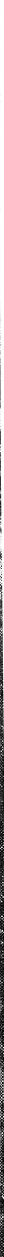

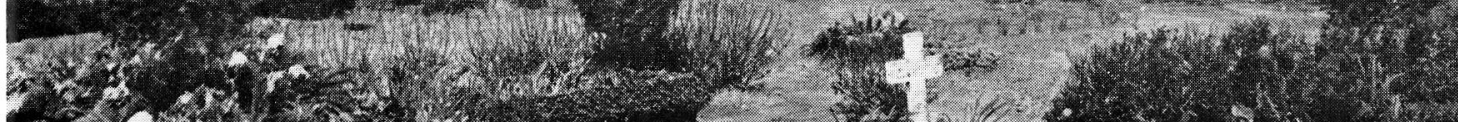
nox $x$

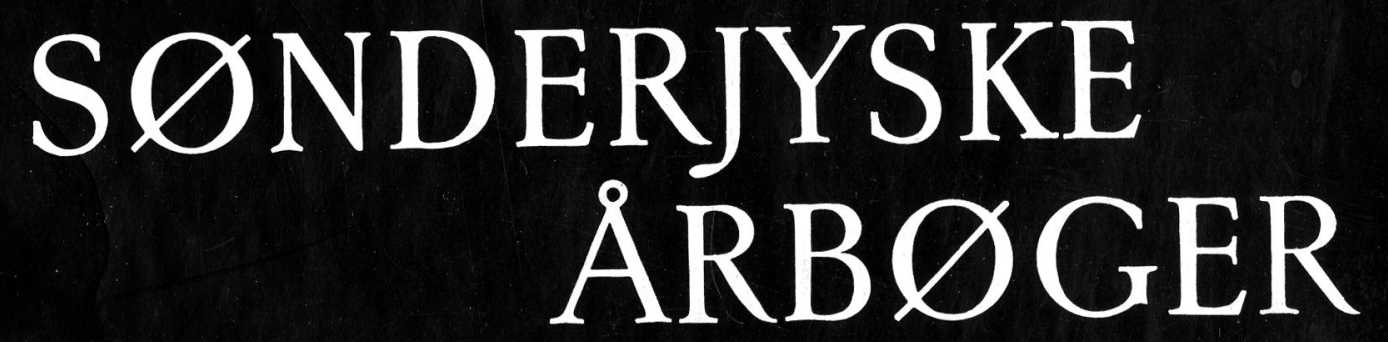

UDGIVET AF

HISTORISK SAMFUND FOR SøNDERJYLLAND 
$\AA$ R S M $\emptyset \mathrm{D} \mathrm{E}$

søndag d. 31. maj kl. 14,00 på

Rugkobbelskolen i Åbenrå.

D a g s orde $n$ :

Beretning.

Regnskab.

Beretning og regnskab

for Sønderjysk månedsskrift.

Valg (efter tur afgår W. Chri-

stiansen, $K$. Fan $\phi, J$. Holdt

og $J$. Hvidtfeldt).

Forslag om lovændringer:

Fra § 2: „Medlemsbidraget fastsættes på årsm $\varnothing$ det « foreslås ændret til: »Medlemsbidraget fastsættes af styrelsen «. Fra $\$ 6$ : »Kalenderåret er samfundets regnskabsår « foreslås ændret til: »Foreningens regnskabsår går fra 1. april til 31. marts «.

Eventuelt.

$K$ a f f e b or d.

Foredrag af overarkivar, dr. phil. Holger Hjelholt: "Martsrevolutionen 1848 i Kiel og Nordslesvig .

Korte foredrag ved museumsinspekt $\varnothing \mathrm{r} H$. Neumann: „Den nye museumsordning og Nordslesvig« og magister $S$. Schoubye: "Tønders s $\varnothing$ lvsmede."

Efter mødet bliver der lejlighed til at bese Rugkobbelskolen.

\section{HALVBIND 1959}

Arkivar Ole Karup Pedersen, København:

Hr. Anker Jensen Buch til Ballum............

Sognepræst $H$. Hejselbjerg Paulsen, Fjelstrup: Fra de nationale valgs tid i Sønderjylland ...

Afd. skoleinspektør $F$. C. C. Linvald:

Knapmageriet i Tønder amt ..............

Adjunkt $H$. V. Gregersen, Struer:

Rådhuset i Åbenrå . . . . 77-88 